\title{
COMPARISON OF DEXMEDETOMIDINE AND ESMOLOL FOR INDUCTION OF CONTROLLED HYPOTENSION IN SPINE SURGERIES
}

Deepali Sidhwani Valecha 1, Monika Gandhi' ${ }^{2}$ K. K. Arora ${ }^{3}$

${ }_{1}^{1}$ Senior Resident, Department of Anaesthesiology, M.G.M. Medical College and M. Y. Hospital, Indore.

${ }^{2}$ Associate Professor, Department of Anaesthesiology, M.G.M. Medical College and M. Y. Hospital, Indore.

3Professor, Department of Anaesthesiology, M.G.M. Medical College and M. Y. Hospital, Indore.

\section{ABSTRACT}

\section{OBJECTIVE}

A comparative study to evaluate the efficacy of dexmedetomidine as a hypotensive agent in comparison to esmolol in Spine surgeries.

\section{METHODS}

60 patients ASA I or II scheduled for routine spine surgeries were equally randomly assigned to receive either dexmedetomidine or esmolol. In DEX group, patients received loading dose of $1 \mu \mathrm{g} / \mathrm{kg}$ dexmedetomidine diluted in $10 \mathrm{~mL} 0.9 \%$ saline infused over 10 min. before induction of anaesthesia, followed by continuous infusion of $0.5 \mu \mathrm{g} / \mathrm{kg} / \mathrm{h}$. In E group, patients received esmolol as a loading dose $1 \mathrm{mg} / \mathrm{kg}$ as $10 \mathrm{~mL}$ total vol. in saline infused over $1 \mathrm{~min}$. followed by continuous infusion of $0.5 \mathrm{mg} / \mathrm{kg} / \mathrm{h}$. In both groups, aim was to maintain MAP within 55-65 mmHg. All patients were premedicated with IV glycopyrrolate $5 \mu \mathrm{g} / \mathrm{Kg}$, IV midazolam 0.05 $\mathrm{mg} / \mathrm{kg}$ and fentanyl $2 \mu \mathrm{g} / \mathrm{kg}$. Patients received standard anaesthetic technique with propofol $2 \mathrm{mg} / \mathrm{kg}$. Anaesthesia was maintained with $\mathrm{O}_{2}, \mathrm{~N}_{2} \mathrm{O}$, sevoflurane at $2 \mathrm{MAC}$ and atracurium $0.1 \mathrm{mg} / \mathrm{kg}$. Surgical field was assessed using Average Category Scale and average blood loss was calculated. Hemodynamic variables (MAP and HR); intraoperative fentanyl consumption; Emergence time and total recovery from anaesthesia (Aldrete score $\geq 9$ ) were recorded. Sedation score was determined at 15, 30, 60 min. after tracheal extubation and time to first analgesic request was recorded.

\section{RESULTS}

Both DEX group and E group reached the desired MAP (55-65 mmHg) with no intergroup differences in MAP or HR. The average category scale for quality of the surgical field in the range of MAP (55-65 mmHg) were $<=2$ with no significant differences between group scores during hypotensive period. The induction propofol dose was significantly lower in DEX group than E group $(1.63 \pm 0.19$ $\mathrm{mg} / \mathrm{kg}$ ) versus $(2.00 \pm 0.05 \mathrm{mg} / \mathrm{kg})$ respectively $(\mathrm{P}<0.000)$. Baseline values of MAP and HR were comparable in both groups. Mean intraoperative fentanyl consumption in DEX group was significantly less than E group $(21.67 \pm 22.75 \mu \mathrm{g} v \mathrm{vs} 7.17 \pm 27.85 \mu \mathrm{g})$. Emergence time and time to achieve $\geq 9$ modified. Aldrete scores were significantly shorter in E group than DEX group $.4 .37 \pm 0.92$ $\mathrm{min}$. and $9.47 \pm 1.61 \mathrm{~min}$. versus $8.5 \pm 1.9 \mathrm{~min}$. and $4.95 \pm 1.24 \mathrm{~min}$. $(\mathrm{P}<0.001)$. Incidence of intraoperative hypotension and bradycardia were seen in Esmolol group in $3.33 \%$ cases.

\section{CONCLUSION}

Both dexmedetomidine and esmolol with sevoflurane are safe agents for controlled hypotension and are effective in providing ideal surgical field during spine surgeries. Compared with esmolol, dexmedetomidine offers the advantage of inherent analgesic, sedative and reduces dose of inducing agent.

\section{KEYWORDS}

Controlled Hypotension, Deliberate Hypotension, Spine Surgeries, Dexmedetomidine, Esmolol.

HOW TO CITE THIS ARTICLE: Valecha DS, Gandhi M, Arora KK. Comparison of dexmedetomidine and esmolol for induction of controlled hypotension in spine surgeries. J. Evolution Med. Dent. Sci. 2016;5(35):2030-2035, DOI: 10.14260/jemds/2016/477

\section{INTRODUCTION}

Induced or controlled hypotension is a method by which the arterial blood pressure is decreased in a predictable and deliberate manner. ${ }^{1}$ The intent of deliberate hypotension is to reduce bleeding and thus facilitate surgery and to decrease the amount of blood transfused. Controlled hypotension is a technique used to limit intraoperative blood loss to provide

Financial or Other, Competing Interest: None.

Submission 16-03-2016, Peer Review 09-04-2016,

Acceptance 16-04-2016, Published 02-05-2016.

Corresponding Author:

Dr. Deepali Sidhwani Valecha,

510 A2 Block, Milan Heights

Near Agarwal Public School,

Bicholi Mardana, Indore.

E-mail: deepalisidhwani@gmail.com

DOI: $10.14260 /$ jemds $/ 2016 / 477$ the best possible field for surgery. ${ }^{2,3} \mathrm{~A}$ dry field results in more precise dissection and less risk of damage to vital structures. Trauma and tissue infection are minimised because fewer sutures are required and less electrocoagulated, devitalised tissue remains in the wound. Initially, induced hypotension was thought to decrease the surgical time due to improved visibility; however, this thought has later been proven to be untrue.

Various agents e.g., magnesium sulphate, ${ }^{4}$ vasodilators (sodium nitroprusside), ${ }^{3}$ nitroglycerin, ${ }^{5}$ high doses of potent inhaled anaesthetics, ${ }^{6}$ and beta-adrenergic antagonist ${ }^{7}$ have been used to achieve controlled hypotension. Some disadvantages have been reported of these techniques including delayed recovery from inhaled anaesthetics, resistance to vasodilators, tachyphylaxis, and cyanide toxicity for nitroprusside. 
Esmolol is an ultra short-acting selective B1 adrenergic antagonist that reduces heart rate and blood pressure. It has rapid onset of action of bolus IV injection and infusion. Upon termination of infusion, gradual recovery of arterial blood pressure to the pre-infusion level occurs without development of rebound hypertension. 8,9

Dexmedetomidine (DEX) is a potent highly selective $\alpha_{2}$ adrenergic receptor agonist. It has sedative, analgesic and anaesthetic sparing effect, and sympatholytic properties. ${ }^{10}$ The central and peripheral sympatholytic action of (DEX) is mediated by $\alpha_{2}$ adrenergic receptor and is manifested by dosedependent decrease in arterial blood pressure, heart rate, cardiac output and norepinephrine release. .11,12 $^{2}$

With increasing numbers and complexity of spine surgery in adults, there is mounting awareness on effects of blood loss on patients' outcomes. ${ }^{13}$ The primary aim of our study was to monitor the lowering of blood pressure with esmolol and dexmedetomidine; and secondarily to compare emergence and recovery time from anaesthesia and the adverse outcomes with dexmedetomidine and esmolol.

\section{METHODS}

The study was carried out in the Department of Anaesthesiology, M.G.M. Medical College and M.Y. Hospital, Indore, M.P. It was a prospective cross-sectional comparative study done over a definite period of time over sixty patients posted for spine surgeries in routine theatre list. The study included sixty patients of age group $20 \mathrm{yrs}$. to $50 \mathrm{yrs}$. of ASA grade 1 and ASA grade 2 . Exclusion criteria ${ }^{14}$ included known cases of COPD, asthma, coagulopathy, hypertensive or diabetic patients, hypovolemic or hypotensive patients, patients with pre-existing severe bradycardia, or ejection fraction $<30 \%$, patients having arrhythmias on ECG or cardiac block, obese patients (BMI>30) and with deranged renal function. After getting the ethical clearance, patients in this study were randomly assigned to receive either dexmedetomidine (DEX group $n=30$ ) or esmolol (E group $n=30$ ). In the operating room, two intravenous cannulae were inserted, one for infusion of dexmedetomidine or esmolol and the other for administration of fluids and other drugs. A 22G radial artery catheter was inserted for continuous measurement of arterial blood pressure.

All patients premedicated with IV glycopyrrolate 5 $\mu \mathrm{g} / \mathrm{Kg}$, IV midazolam $0.05 \mathrm{mg} / \mathrm{kg}$ and fentanyl $2 \mu \mathrm{g} / \mathrm{Kg}$. In DEX group, patients received loading dose of $1 \mu \mathrm{g} / \mathrm{kg}$ dexmedetomidine diluted in $10 \mathrm{~mL} 0.9 \%$ saline infused over $10 \mathrm{~min}$. before induction of anaesthesia, followed by continuous infusion of $0.5 \mu \mathrm{g} / \mathrm{kg} / \mathrm{h}$. In E group, patients received esmolol as a loading dose $1 \mathrm{mg} / \mathrm{kg}$ as $10 \mathrm{~mL}$ total vol in saline to be infused over $1 \mathrm{~min}$. followed by continuous infusion of $0.5 \mathrm{mg} / \mathrm{kg} / \mathrm{h}$. In both groups, aim was to maintain MAP within 55-65 mmHg. Patients received standard anaesthetic technique, induction with propofol $2 \mathrm{mg} / \mathrm{kg}$ supplemented if necessary by $0.2 \mathrm{mg} / \mathrm{kg}$ aliquots until loss of verbal response. The required induction doses of propofol were recorded. Endotracheal intubation is facilitated with atracurium $0.5 \mathrm{mg} / \mathrm{kg}$ with suitable sized cuffed tube. Anaesthesia was maintained with $\mathrm{O}_{2}, \mathrm{~N}_{2} \mathrm{O}$, sevoflurane at 2 vol\% and atracurium $0.1 \mathrm{mg} / \mathrm{kg}$. All patients were mechanically ventilated with $60 \% \mathrm{~N}_{2} \mathrm{O} / 40 \% \mathrm{O}_{2}$ mixture and sevoflurane at 2 vol \%.
In both groups, signs of inadequate anaesthesia as increase in the arterial pressure greater than the targeted MAP were treated with nitroglycerin $1 \mu \mathrm{g} / \mathrm{kg} / \mathrm{min}$ infused if these target limits could not be achieved. The somatic responses as movement or sweating were treated with additional dose of fentanyl $1 \mu \mathrm{g} / \mathrm{kg}$. Respiratory rate (RR) and tidal volume (TV) were adjusted according to body weight to maintain normocapnia. Patients received Ringer lactate at $3 \mathrm{~mL} / \mathrm{kg}$ Bradycardia associated with these drugs was treated with Atropine $0.01 \mathrm{mg} / \mathrm{kg}$ dose. The surgeons were blinded to the hypotensive agent used and were explained the Average category scale. When MAP reached desired range (55-65 $\mathrm{mmHg}$ ) and maintained for at least 10 minutes, the surgeon assessed the quality of the surgical field using a predefined average category scale adopted from that of Frommeet al. ${ }^{15}$ The ideal category scale values for surgical condition is 2 . The total blood loss was measured from the suction apparatus. Infusion of the study drugs and sevoflurane was stopped five minutes before the anticipated end of surgery, and N2O stopped at the end of the surgery and the residual neuromuscular blockade antagonised with neostigmine $(0.05$ $\mathrm{mg} / \mathrm{kg}$ ) and glycopyrrolate $(10 \mu \mathrm{g} / \mathrm{kg})$.

Monitoring included invasive blood pressure measurement, heart rate, and surgical field score (Average Category scale). Intraoperative fentanyl consumption and requirements for additional hypotensive agent (nitroglycerin) were recorded. Emergence time ${ }^{16}$ (interval between the discontinuation of anaesthetics to response of eye opening to verbal command) was recorded. After extubation and full recovery, patients were transferred to the post-anaesthesia care unit (PACU) and observed where time to first analgesic rescue was recorded. Postoperative recovery evaluated using Aldrete score ${ }^{17}(0-10)$. Sedation score ${ }^{18}$ was measured at 15 , 30 and 60 minutes after tracheal extubation.

\section{STATISTICS}

Continuous variables were described as mean +- standard deviation (S.D.) and differences between both groups were analysed using student $\mathrm{T}$ test for two sample proportions for normally distributed data. Categorised variables were described as frequency and analysed by the Pearson chisquare test. $P$ value less than 0.05 was considered significant. All statistical analyses were performed using MINITAB version 17.

\section{RESULTS}

Patients of the study groups were comparable with respect to demographic data and operative data [Table 1]. The induction propofol dose was significantly lower in DEX group than E group $(1.63 \pm 0.19 \mathrm{mg} / \mathrm{kg})$ versus $(2.00 \pm 0.05 \mathrm{mg} / \mathrm{kg})$ respectively $(\mathrm{P}<0.001)$. Baseline values of MAP and HR were comparable in both groups. In DEX and E groups, there was a significant reduction of MAP in both groups compared to baseline value intraoperatively. Both groups reached the desired MAP (55-65 mmHg) with no intergroup significant differences after induction or during hypotensive period. In esmolol group, there was need to use nitroglycerin as an additional hypotensive agent intraoperatively in one out of 30 cases. At 5 and 10 minutes after stoppage of hypotensive agents, at end of surgery and after recovery, MAP was significantly lower in DEX group than E group [Figure 1]. 
Heart rate decreased significantly relative to baseline after administration of loading dose in both groups. There were no intergroup significant differences in HR after induction or during the hypotensive period. HR showed significant increase in E group 5, $10 \mathrm{~min}$. after stoppage of hypotensive agent, at end of surgery and after recovery compared to DEX group [Figure 2]. Mean intraoperative fentanyl consumption in DEX group was significantly less than E group $(21.67 \pm 22.75 \mu \mathrm{g}$ vs $77.17 \pm 27.85 \mu \mathrm{g} 6$ [Fig 2]).

The average category scale (ACS) for quality of surgical field was comparable in both groups in the range of MAP (55-65 mmHg). Scores for bloodless surgical field were low in both groups; there was no significant difference in between group scores. The median range of scores was 2 (1-2) in both groups. The scores were $\leq 2$ through the hypotensive period [Table 2]. There was no significant difference in the amount of blood loss intraoperatively in both groups. No patients presented with excessive blood loss. Emergence time and time needed to achieve $\geq 9$ of modified Aldrete score were significantly shorter in E group than DEX group (4.37 \pm 0.92$)$ min. and $9.47 \pm 1.61 \mathrm{~min}$. versus $(8.5 \pm 1.9 \mathrm{~min})$ and $4.95 \pm 1.24$ min. respectively) $(\mathrm{P}<0.01)$ [Table 5].

The mean postoperative sedation scores were significantly lower in E group than in DEX group at $15 \mathrm{~min}$. $2.17 \pm 0.38 \mathrm{~min}$. vs. $3.37 \pm 0.49 \mathrm{~min} .(\mathrm{p}<0.01)$ and $30 \mathrm{~min}$. $2.30 \pm 0.46$ vs. $2.07 \pm 0.25$ ( $\mathrm{p}<0.016$ ). No significant difference was observed in sedation score at $60 \mathrm{~min}$. in both groups. In both groups, no patient complains of any sign of awareness [Table 3]. Time recorded to first analgesic request was significantly shorter in E group than DEX group (25.83 \pm 8.71 $\mathrm{min}$.) vs $(76.03 \pm 32.68 \mathrm{~min}$.) respectively $(\mathrm{P}<0.001)$. [Table 5]. No postoperative nausea or vomiting observed in both groups.

$(\mathrm{N}=30)$

\begin{tabular}{|c|c|c|c|c|}
\hline Parameter & $\begin{array}{c}\text { Group I } \\
\text { (Dex) }\end{array}$ & $\begin{array}{c}\text { Group II } \\
\text { (Esmolol) }\end{array}$ & $\begin{array}{c}\text { t } \\
\text { value }\end{array}$ & $\begin{array}{c}\text { P } \\
\text { value }\end{array}$ \\
\hline $\begin{array}{c}\text { Age } \\
\text { (years) }\end{array}$ & $36.83 \pm 7.65$ & $36.60 \pm 8.29$ & 0.113 & $\begin{array}{c}\mathrm{P}= \\
0.910\end{array}$ \\
\hline $\begin{array}{c}\text { Weight } \\
\text { (kg) }\end{array}$ & $58.33 \pm 6.77$ & $60.60 \pm 6.78$ & - & $\begin{array}{c}\mathrm{P}= \\
0.296\end{array}$ \\
\hline \multicolumn{4}{|c|}{ Table 1: Mean Age and Weight in both the Groups } \\
\hline
\end{tabular}

* Significant

\begin{tabular}{|c|c|c|c|c|}
\hline ACS & $\begin{array}{c}\text { Group I } \\
\text { (Dex) }\end{array}$ & $\begin{array}{c}\text { Group II } \\
\text { (Esmolol) }\end{array}$ & $\begin{array}{c}\text { t } \\
\text { value }\end{array}$ & $\begin{array}{c}\text { P } \\
\text { value }\end{array}$ \\
\hline At $15 \mathrm{~min}$ & $1.93 \pm 0.25$ & $1.97 \pm 0.41$ & 0.38 & 0.708 \\
\hline At $30 \mathrm{~min}$ & $1.87 \pm 0.34$ & $1.96 \pm 0.25$ & 1.40 & 0.167 \\
\hline At $45 \mathrm{~min}$ & $1.80 \pm 0.40$ & $1.96 \pm 0.36$ & 1.76 & 0.08 \\
\hline At $60 \mathrm{~min}$ & $1.73 \pm 0.45$ & $1.93 \pm 0.36$ & 1.89 & 0.06 \\
\hline \multicolumn{5}{|c|}{ Table 2: Average Category Scale (ACS) at Different Time } \\
Intervals in both the Groups \\
\hline
\end{tabular}

* Significant

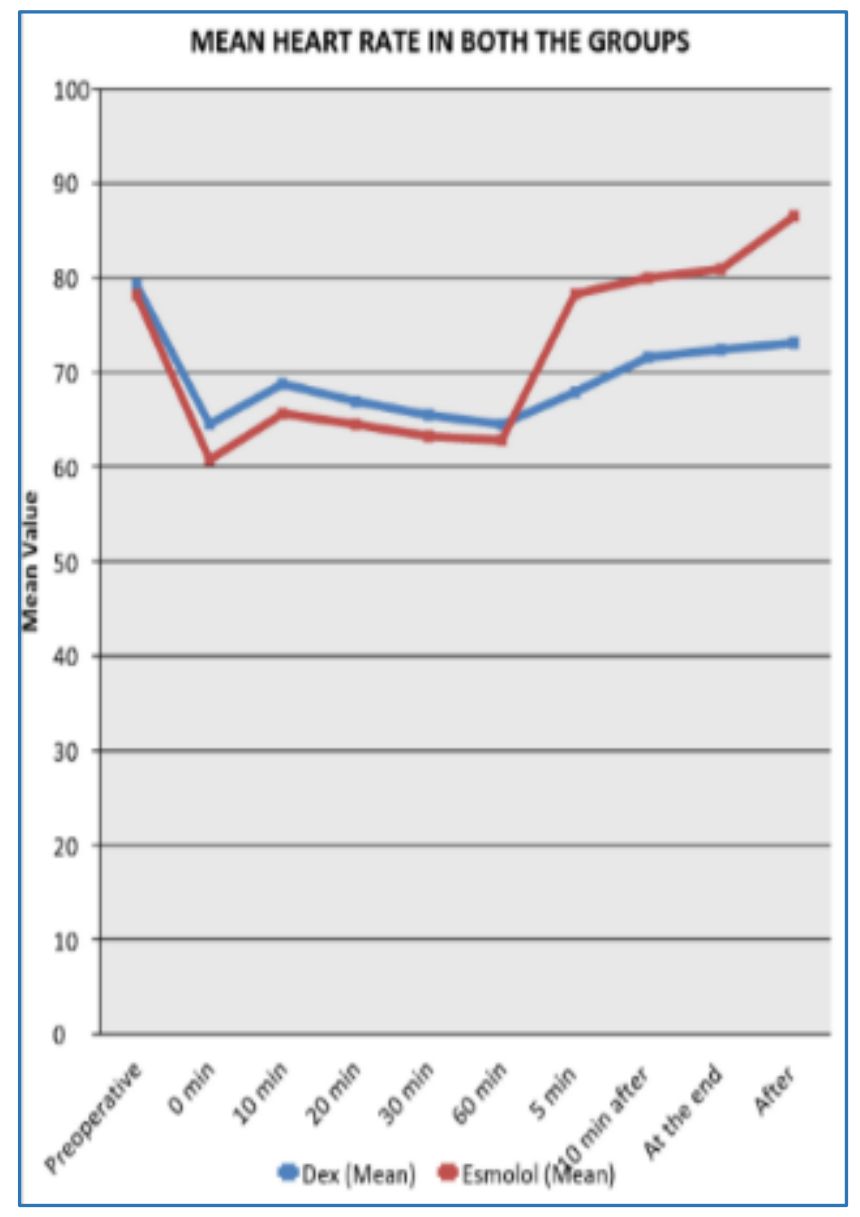

Fig. 1

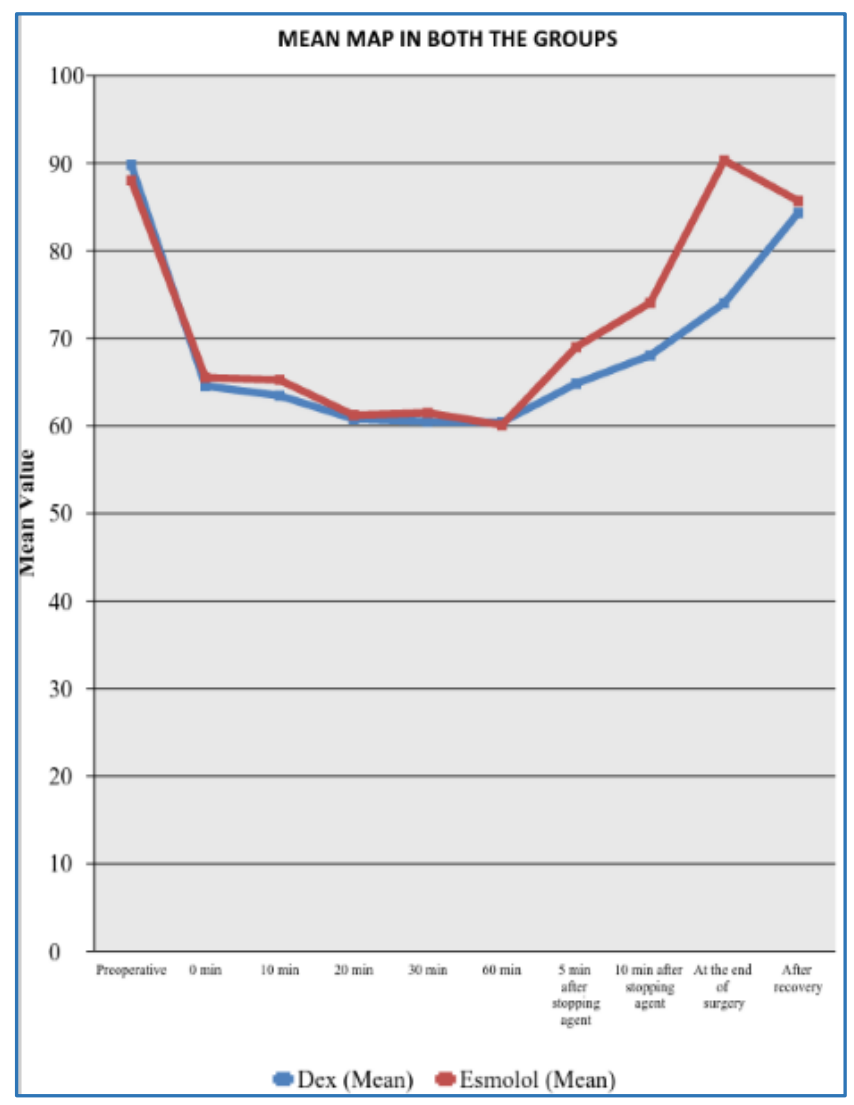

$(\mathrm{N}=30)$
Fig. 2 


\begin{tabular}{|c|c|c|c|c|}
\hline $\begin{array}{c}\text { Sedation } \\
\text { Score }\end{array}$ & $\begin{array}{c}\text { Group I } \\
\text { (Dex) }\end{array}$ & $\begin{array}{c}\text { Group II } \\
\text { (Esmolol) }\end{array}$ & $\begin{array}{c}\text { t } \\
\text { value }\end{array}$ & $\begin{array}{c}\text { P } \\
\text { value }\end{array}$ \\
\hline $\begin{array}{c}\text { Sedation } \\
\text { score at } 15 \\
\text { min }\end{array}$ & $\begin{array}{c}3.37 \pm \\
0.49\end{array}$ & $2.17 \pm 0.38$ & 10.61 & $0.000^{*}$ \\
\hline $\begin{array}{c}\text { Sedation } \\
\text { score at } 30 \\
\text { min }\end{array}$ & $\begin{array}{c}2.30 \pm \\
0.46\end{array}$ & $2.07 \pm 0.25$ & 2.40 & $0.019^{*}$ \\
\hline $\begin{array}{c}\text { Sedation } \\
\text { score at 60 } \\
\text { min }\end{array}$ & $\begin{array}{c}2.13 \pm \\
0.34\end{array}$ & $2.06 \pm 0.00$ & 0.85 & 0.398 \\
\hline \multicolumn{5}{|c|}{ Table 3: Sedation Score at Different Time Intervals } \\
\hline
\end{tabular}

* Significant

$(\mathrm{N}=30)$

\begin{tabular}{|c|c|c|c|c|}
\hline Parameter & $\begin{array}{c}\text { Group I } \\
\text { (Dex) }\end{array}$ & $\begin{array}{c}\text { Group II } \\
\text { (Esmolol) }\end{array}$ & $\begin{array}{c}\text { t } \\
\text { value }\end{array}$ & $\begin{array}{c}\text { P } \\
\text { value }\end{array}$ \\
\hline $\begin{array}{c}\text { Emergence } \\
\text { time (min) }\end{array}$ & $8.50 \pm 1.91$ & $4.37 \pm 0.923$ & 10.674 & $0.000^{*}$ \\
\hline $\begin{array}{c}\text { Time to } \\
\text { Modified } \\
\text { Aldret } \\
\text { score (>9) } \\
\text { (min) }\end{array}$ & $9.47 \pm 1.61$ & $4.95 \pm 1.24$ & 12.16 & $0.000^{*}$ \\
\hline $\begin{array}{c}\text { Table 4: Comparison of Time to Modified Aldrete Score } \\
\text { (>9) \& Emergence Time between the Two Groups }\end{array}$ \\
\hline
\end{tabular}

* Significant

\begin{tabular}{|c|c|c|c|c|}
\hline Parameters & $\begin{array}{c}\text { Group I } \\
\text { (Dex) }\end{array}$ & $\begin{array}{c}\text { Group II } \\
\text { (Esmolol) }\end{array}$ & $\begin{array}{c}\text { t } \\
\text { value }\end{array}$ & $\begin{array}{c}\text { P } \\
\text { value }\end{array}$ \\
\hline $\begin{array}{c}\text { Propofol } \\
\text { requirement } \\
\text { (mg) }\end{array}$ & $1.63 \pm 0.19$ & $2.00 \pm 0.05$ & 10.19 & $0.000^{*}$ \\
\hline $\begin{array}{c}\text { Additional } \\
\text { analgesic } \\
\text { requirement } \\
\text { (mcg) }\end{array}$ & $21.67 \pm 22.75$ & $77.17 \pm 27.87$ & 8.44 & $0.000^{*}$ \\
\hline $\begin{array}{c}\text { Time for first } \\
\text { analgesic } \\
\text { requirement } \\
\text { (min) }\end{array}$ & $76.03 \pm 32.68$ & $25.83 \pm 8.72$ & 8.12 & $0.000^{*}$ \\
\hline \multicolumn{3}{|c|}{ Table 5: Comparison of Propofol Requirement, Additional } \\
Analgesic Requirement and Time for First Analgesic \\
Requirement in both the Groups \\
\hline
\end{tabular}

* Significant

\section{DISCUSSION}

Induced hypotension has been widely used and advocated to control the bleeding and thus improve the quality of surgical field. In our study, we used dexmedetomidine or esmolol along with sevoflurane as hypotensive agents to maintain MAP between 55-65 $\mathrm{mmHg}$ to provide the optimal surgical field. Both the drugs were effective in achieving MAP of 55-65 $\mathrm{mmHg}$ and lowering the heart rate ensured good surgical condition and providing dry surgical field during spine surgeries.

Patients who were treated with dexmedetomidine 10 min. before induction of anaesthesia had significant decrease in MAP and HR after administration of loading dose. This dexmedetomidine induced haemodynamic profile can be attributed to the known sympatholytic effect of $\alpha 2$ agonists.
The $\alpha 2$ receptors are involved in regulating the autonomic and cardiovascular systems. Alpha 2 receptors are located on blood vessels, where they mediate vasoconstriction, and on sympathetic terminal, where they inhibit norepinephrine release. The efficacy of dexmedetomidine in providing better surgical field and less blood loss during controlled hypotension was previously reported during middle ear surgeries by Ossama $\mathrm{H}$ et. Al. ${ }^{19}$ Richa et.al. ${ }^{12}$ demonstrated it in maxillofacial surgeries. Similar results were seen by Tarek Shams et.al. ${ }^{20}$ and Bayrams et.al. ${ }^{21}$ in FESS.

Esmolol administration in the present study was associated with significant decrease in MAP and heart rate compared to baseline values. Esmolol lowers arterial blood pressure through a decrease in cardiac output secondary to negative chronotropic and inotropic effects of $\beta$ adrenergic antagonism. ${ }^{22}$ It provided a stable course of controlled hypotension and produced beneficial effects in surgical field and in blood conservation. Similar findings were seen by Boezaart et.al. ${ }^{23}$ and Tareek Shams et. $\mathrm{Al}^{20}$ in FESS.

In our study baseline values of MAP and HR were comparable in both groups. In DEX and E groups, there was significant reduction of MAP in both the groups compared to baseline values intraoperatively. Both groups reached the desired MAP (55-65 mmHg) with no intergroup significant differences after induction or during hypotensive period. At 5 and 10 minutes after stoppage of hypotensive agents, at end of surgery and after recovery, MAP was significantly lower in DEX group than E group. Heart rate decreased significantly relative to baseline after administration of loading dose in both groups. There were no intergroup significant differences in HR after induction or during the hypotensive period.

HR showed significant increase in E group 5, 10 min. after stoppage of hypotensive agent, at end of surgery and after recovery compared to DEX group than E group. Heart rate decreased significantly relative to baseline after administration of loading dose in both groups.

In our study, the mean induction dose of propofol in DEX group was $1.63 \pm 0.19 \mathrm{mg} / \mathrm{kg}$ and in esmolol group was $2.00 \pm 0.05 \mathrm{mg} / \mathrm{kg}$. The difference in both the groups is statistically significant having $P$ value of $<0.000$. Induction dose of propofol is reduced with dexmedetomidine as compared to esmolol. Our study results are supported by study done by Peden et al. $^{24}$ (2001) where the effect of intravenous dexmedetomidine premedication on the dose requirement of propofol to induce the loss of consciousness in patients receiving alfentanil was done and they found that dexmedetomidine causes reduction in the overall concentration and dose of propofol required to produce loss of consciousness. Similar profile was noted by Guven et al. ${ }^{25}$ and Goksu et al. ${ }^{26}$

In our study in esmolol group, there was a case of failure where nitroglycerin infusion was started as esmolol was not able to achieve target MAP. In DEX group there was no need to use nitroglycerin as an additional hypotensive agent.

The average category scale (ACS) for quality of surgical field was comparable in both groups in our study where the ACS during the hypotensive period was $\leq 2$.

There was no significant difference in the amount of blood loss intraoperatively in both groups.

No patients presented with excessive blood loss and there was no need to transfuse blood in any patient. In our study, mean intraoperative fentanyl consumption in DEX 
group was $21.67 \pm 22.75 \mu \mathrm{g}$ which was significantly less than $77.17 \pm 27.85 \mu \mathrm{g}$ observed in $\mathrm{E}$ group. Our results are supported by the study done by Gurbet et.al. ${ }^{27}$ that showed that intraoperative use of dexmedetomidine reduces the postoperative morphine requirement. Dexmedetomidine by its action through $\alpha 2 \mathrm{~A}$ receptors in the Locus Coeruleus (Site of origin for the descending medullo-spinal noradrenergic pathway, known to be an important modulator of nociceptive neurotransmission terminates the propagation of pain signals leading to analgesia. ${ }^{28}$ Several studies have found that perioperative use of dexmedetomidine was associated with a significant decrease in the consumption of inhalational agent, fentanyl, and analgesic in dose dependent manner. ${ }^{29,30}$

The time recorded to first analgesic request was significantly shorter in E group than DEX group $(25.83 \pm 8.71$ min.) vs $(76.03 \pm 32.68 \mathrm{~min}$. $)$ respectively $(\mathrm{P}<0.001)$. Dexmedetomidine prolonged postoperative analgesia in (DEX) group. This is in accordance with Gurbet et al. ${ }^{27}$ The analgesic effects of dexmedetomidine had been appreciated in various setting and various population. 31,32,33,34

Dexmedetomidine was associated with significant longer emergence time and time to total recovery from anaesthesia compared to esmolol. ${ }^{35}$ Emergence time and time needed to achieve $\geq 9$ of modified Aldrete score were significantly shorter in E group than DEX group, $((4.37 \pm 0.92) \mathrm{min}$. and $9.47 \pm 1.61$ min. versus $(8.5 \pm 1.9 \mathrm{~min})$ and $4.95 \pm 1.24 \mathrm{~min}$. respectively) $(\mathrm{P}<0.01)$.

The mean postoperative sedation scores were significantly lower in E group than in DEX group at $15 \mathrm{~min}$. $2.17 \pm 0.38 \mathrm{~min}$. vs. $3.37 \pm 0.49 \mathrm{~min} .(\mathrm{p}<0.01)$ and $30 \mathrm{~min}$. $2.30 \pm 0.46$ vs. $2.07 \pm 0.25(\mathrm{p}<0.016)$ No significant difference was observed in sedation score at $60 \mathrm{~min}$. postoperatively in both groups. Richa et al. ${ }^{12}$ reported that extubation time was significantly slower in patients receiving dexmedetomidine compared with those receiving remifentanil for controlled hypotension. In both groups, no patient complains of any sign of awareness. Incidence of bradycardia ( $\mathrm{HR}<45 / \mathrm{min})$ and hypotension (MAP $<50 \mathrm{mmHg}$ ) was noticed in one case out of thirty in esmolol group. Both bradycardia and hypotension were noticed after giving a loading dose of esmolol before induction.

\section{CONCLUSION}

I. Dexmedetomidine and esmolol were equally efficacious in reducing MAP and HR in spine surgeries. (providing bloodless field)

II. Compared with esmolol, dexmedetomidine offered the advantage of being inherent analgesic, sedative and also reducing the dose of inducing agent propofol.

Hence, this study found dexmedetomidine to be the preferred agent for induction of controlled hypotension in spine surgeries.

\section{REFERENCES}

1. Cushing H. Tumors of the nervus acusticus. Philadelphia: Saunders WB, 1917.

2. Tobias JD. Controlled hypotension in children: a critical review of available agents. Paediatric Drugs 2002;4(7):439-53.
3. Degoute CS, Ray MJ, Manchon M, et al. Remifentanil and controlled hypotension: comparison with nitroprusside or esmolol during tympanoplasty. Can J Anaesth 2001;48(1):20-7.

4. Elsharnouby NM, Elsharnouby MM. Magnesium sulphate as a technique of hypotensive anesthesia. Br J Anaesth 2006;96(6):727-31.

5. Degoute CS, Dubreuil C, Ray MJ, et al. Effect of posture, hypotension and locally applied vasoconstriction on the middle ear microcirculation in anaesthetized humans. Eur J Appl Physiol Occup Physiol 1994;69(5):414-20.

6. Pavlin JD, Colley PS, Weymuller EA, et al. Propofol versus isoflurane for endoscopic sinus surgery. Am J Otolaryngol 1999;20(2):96-101.

7. Degoute CS. Controlled hypotension: guide to drug choice. Drugs 2007;67(7):1053-76.

8. Ornstein E, Young WL, Ostapkovich N, et al. Deliberate hypotension in patients with intracranial arteriovenous malformations: esmolol compared with isoflurane and sodium nitroprusside. Anesth Analg 1991;72(5):639-44.

9. Blowey DL. Antihypertensive agents: mechanism of action, safety profiles, and current uses in children. Curr Ther Res Clin Exp 2001;62(4):298-313.

10. Bloor BC, Ward DS, Belleville JP, et al. Effect of intravenous dexmedetomidine in humans. 11. Hemodynamic changes. Anesthesiology 1992;77(6):1134-42.

11. Schmelling WT, Kampine JP, Roerig DL, et al. The effect of the stereoisomers of the $\alpha 2$-adrenergic agonist dexmedetomidine on systemic and coronary haemodynamics in conscious dogs. Anesthesiology 1991;75(3):499-511.

12. Richa F, Yazigi A, Sleilaty G, et al. Comparison between dexmedetomidine and remifentanil for controlled hypotension during tympanoplasty. Eur J Anaesthesiol 2008;25(5):369-74.

13. Elgafy $\mathrm{H}$, Bransford RJ, McGuire RA, et al. Blood loss in major spine surgery: are there effective measures to decrease massive haemorrhage in major spine fusion surgery. Spine (Phil Pa 1976) 2010;35(9):S47-56.

14. Fahmy Nabil M. Indications and contraindications for deliberate hypotension with a review of its cardiovascular effects. International Anesthesiology Clinics 1979;17(1):175-87.

15. Fromme GA, MacKenzie RA, Gould AB, et al. Controlled hypotension for orthognathic surgery. Anesth Analg 1986;65(6):683-6.

16. Chung F. Are discharge criteria changing? J Clin Anesth 1993;5(6 Suppl 1):64S-68S.

17. Aldrete JA. The post-anesthesia recovery score revisited. J Clin Anesth 1995;7(1):89-91.

18. Ramsay MA, Savege TM, Simpson BR, et al. Controlled sedation with alphaxalone-alphadolone. $\mathrm{Br}$ Med J 1974;2(5920):656-9.

19. Ossama H Aboushanab, Ahmed M El-Shaarawy, Ahmed M Omar, et al. A comparative study between magnesium sulphate and dexmedetomidine for deliberate hypotension during middle ear surgery. Egyptian journal of anaesthesia 2011;27(4):227-32. 
20. Tarek Shams, Nahla S El Bahnasawe, Mohamed AbuSamra, et al. Induced hypotension for functional endoscopic sinus surgery: a comparative study of dexmedetomidine versus esmolol. Saudi J Anaesth 2013;7(2):175-80.

21. Adnan Bayram, Ayșe Ülgey, Işın Güneş, et al. Comparison between magnesium sulphate and dexmedetomidine in controlled hypotension during functional endoscopic sinus surgery. Brazilian Journal of Anesthesiology 2015;65(1):61-7.

22. Richard I Hall. Esmolol just another beta blocker? Can J Anaesth 1992;39(8):757-64.

23. Boezaart AP, van der Merwe J, Coetzee A. Comparison of sodium nitroprusside-and esmolol-induced controlled hypotension for functional endoscopic sinus surgery. Can J Anaesth 1995;42(5 Pt 1):373-6.

24. Peden CJ, Cloote AH, Stratford N, et al. The effect of intravenous dexmedetomidine premedication on the dose requirement of propofol to induce loss of consciousness in patients receiving alfentanil. Anaesthesia 2001;56(5):408-13.

25. Guven DG, Demiraran Y, Sezen G, et al. Evaluation of outcomes in patients given dexmedetomidine in functional endoscopic sinus surgery. Ann Otol Rhinol Laryngol 2011;120(9):586-92.

26. Goksu S, Arik H, Demiryurek S, et al. Effects of dexmedetomidine infusion in patients undergoing functional endoscopic sinus surgery under local anaesthesia. Eur J Anaesthiol 2008;25(1):22-8.

27. Gurbet A, Basagan-Mogol E, Turker G, et al. Intraoperative infusion of dexmedetomidine reduces perioperative analgesic requirements. Drugs 2007;67(7):1053-76.
28. Jones ME, Maze M. Can we characterize the central nervous system actions of $\alpha$ - adrenergic agonists? British Journal of Anaesthesia 2001;86(1):1-3.

29. Aantaa R, Jaakola ML, Kallio A, et al. Reduction of the minimum alveolar concentration of isoflurane by dexmedetomidine. Anesthesiology 1997;86(5):1055-60.

30. Scheinin $H$, Jaakola ML, Sjövall S, et al. Intramuscular dexmedetomidine as premedication for general anaesthesia. A comparative multicenter study. Anesthesiology 1993;78(6):1065-75.

31. Huncke TK, Adelman M, Jacobowitz G, et al. A prospective randomized, placebo-controlled study evaluating the efficacy of dexmedetomidine for sedation during vascular procedures. Vasc Endovasc Surg 2010;44(4):257-61.

32. Taghinia AH, Shapiro FE, Slavin SA. Dexmedetomidine in anaesthetic facial surgery: improving anaesthetic safety and efficacy. Plast Reconstre Surg 2008;121(1):269-76.

33. Gómez-Vázquez ME, Hernández-Salazar E, HernándezJiménez A, et al. Clinical analgesic efficacy and side effects of dexmedetomidine in the early postoperative period after arthroscopic knee surgery. J Clin Anesth 2007;19(8):576-82.

34. Karaaslan K, Yilmaz F, Gulcu N, et al. Comparison of dexmedetomidine and midazolam for monitored anaesthesia care combined with tramadol via patientcontrolled analgesia in endoscopic nasal surgery: a prospective, randomized, double-blind, clinical study. Curr Ther Res Clin Exp 2007;68(2):69-81.

35. Aho M, Erkola 0, Kallio A, et al. Comparison of dexmedetomidine and midazolam sedation and antagonism of dexmedetomidine with atipamezole. J Clin Anesth 1993;5(3):194-203. 